\title{
IN VITRO CYTOTOXIC ACTIVITY OF RODENT TUBER MUTANT PLANT (TYPHONIUM FLAGELLIFORME LODD.) AGAINST TO MCF-7 BREAST CANCER CELL LINE
}

\author{
NESTI FRONIKA SIANIPAR ${ }^{1,2 *}$, KHOIRUNNISA ASSIDQI ${ }^{2}$, RAGAPADMI PURNAMANINGSIH ${ }^{3}$, TATI HERLINA ${ }^{4}$ \\ ${ }^{1}$ Department of Food Technology, Faculty of Engineering, Bina Nusantara University, Jakarta 11480, Indonesia. ${ }^{2}$ Research Interest \\ Group Food Biotechnology, Bina Nusantara University, Jakarta 11480, Indonesia. ${ }^{3}$ Indonesian Center for Agricultural Biotechnology and \\ Genetic Resources Research and Development (BB-Biogen), 16111 Bogor, Indonesia. ${ }^{4}$ Department of Chemistry, Mathematics and Science \\ Faculty, Padjajaran University, Jatinangor 45363, Sumedang, Indonesia. Email: nsianipar@binus.edu
}

Received: 10 September 2018, Revised and Accepted: 21 November 2018

\section{ABSTRACT}

Objective: The objective of this study was to determine the new bioactive compounds through gas chromatography-mass spectrometry analysis and the cytotoxic activity of two rodent tuber mutant plants against breast cancer cells (MCF-7).

Methods: The bioactive compounds in rodent tuber mutant plants were successfully increased by somaclonal variation using gamma rays irradiation technique. Further, the cytotoxicity activity of rodent tuber mutant plants was tested on breast cancer cell line (MCF-7) performed by 3-(4,5-dimethythiazol-2-yl)-2,5-diphenyltetrazolium bromide assay method.

Results: This results study confirmed that the presence of phytochemical composition in the tuber of rodent tuber mutant plants KB 6-1-3-4 and KB 6-9-5 was found six bioactive compounds from fatty acid groups which have the potential as an anticancer compound, such as octadecanoic acid, hexadecanoic acid, hexadecanoic acid methyl ester, 9-octadecanoic acid, linolelaidic acid methyl ester, and butanoic acid. The results showed that extracts from rodent tuber mutant plants had a cytotoxicity effect on MCF-7 cancer cells with half maximal inhibitory concentration (IC I $_{50}$ values that were lower than the control (mother plant). In vitro tests of KB 6-1-3-4 and KB 6-9-5 against MCF-7 cancer cell lines have IC ${ }_{50}$ values of $12.482 \mu \mathrm{g} / \mathrm{mL}$ and $7.043 \mu \mathrm{g} / \mathrm{mL}$, respectively, while it had a lower cytotoxicity effect with the $\mathrm{IC}_{50}$ value of control plant was $19.113 \mu \mathrm{g} / \mathrm{mL}$. The mutant plants of KB 6-9-5 have 3 times more effective than control.

Conclusion: The results of this study clearly indicated that rodent tuber mutant plants have shown promising as an anticancer drug on breast cancer.

Keywords: Typhonium flagelliforme Lodd., Anticancer, MCF-7 cell, Gas chromatography-mass spectrometry analysis, Fatty acids.

(c) 2019 The Authors. Published by Innovare Academic Sciences Pvt Ltd. This is an open access article under the CC BY license (http://creativecommons. org/licenses/by/4. 0/) DOI: http://dx.doi.org/10.22159/ajpcr.2019.v12i3.29651

\section{INTRODUCTION}

Rodent tuber (Typhonium flagelliforme Lodd.) is the Araceae family and classified as herbal plants [1]. Plant propagation methods are carried out vegetatively by separating the shoots [1]. Many studies investigated that rodent tuber has bioactive compounds as anticancer, antiviral, antibacterial, and antioxidant agents [2-4]. Rodent tuber was found to possess useful anticancer activities such as in breast, intestine, prostate gland, liver, leukemia, and cervix $[2,5,6]$. In vitro mutagenesis was carried out using a combination of gamma-ray irradiation and somaclonal variation to increase the bioactive compounds in rodent tuber plants. The rodent tuber mutant plants have morphology changes [7], genetic changes $[8,9]$, and protein expression changes [10]. Morphological, genetic, and protein expression changes can reinforce the bioactive compounds in mutant plants. Sianipar and Purnamaningsih [11] had investigated that bioactive compounds in several mutant clones from Bogor have been increased.

Genetic mutations can be used and the number of phytochemical components in plants, which can be detected by gas chromatographymass spectrometry (GC-MS). GC-MS has been used to determine the content of herbal plants such as Melia orientalis [12], Maranta arundinacea L. [13], and non-polar fractions of Malaysian rodent tuber [6]. Extracts of the rodent tuber plant have been applied to several cancer cells in vitro. Rodent tuber extract with ethanol fraction has been shown to be effective in inhibiting the growth of T47D breast cancer cells [14], inhibiting the proliferation of T4-lymphoblastoid human cancer cells $[4,5]$ and can inhibit the growth of cell cultures of non-small cell lung carcinoma NCI-H23 [2]. The anticancer activity test can be carried out by antiproliferative extract test on the growth of cancer cells using the clonogenic assay method $[15,16]$. The 3-(4,5-dimethythiazol2-yl)-2,5-diphenyltetrazolium bromide (MTT) method has been used to determine anticancer activity in rodent tuber $[2,4,14]$. The aimed of this study was to determine the new bioactive compounds through GC-MS analysis and has a cytotoxic activity of two mutant clones (KB 6-1-3-4 and KB 6-9-5) against MCF-7 breast cancer cell lines.

\section{METHODS}

\section{Plant material}

Rodent tuber plant material is used from Bogor. Rodent tuber has been irradiated by gamma-ray to produce in vitro mutagenesis and obtained rodent tuber mutant plants. Two mutant plants of KB 6-1-3-4, KB 6-9-5, and control plant (mother plant) were acclimatized and maintained at Indonesian Center for Agricultural Biotechnology and Genetic Resources Research and Development, Ministry of Agriculture, Bogor, Indonesia. The rodent tuber mutant plants were harvested and dried to extract all substances.

\section{Preparation of rodent tuber mutant extract}

Rodent tuber mutant plants KB 6-1-3-4, KB 6-9-5, and control plants were harvested and cleaned the tubers, then cut into small pieces and weighed. The tuber samples were macerated using ethanol for $24 \mathrm{~h}, 2$ times repetition [17]. The samples were filtered using Whatman paper No.1, and the filtrate was evaporated using a rotary evaporator at $40^{\circ} \mathrm{C}$ to obtain a crude extract of rodent tuber. Extraction results are put into a sample bottle and dried using freeze drier. 


\section{GC-MS analysis}

The ethanol fraction of the sample was injected into the GC column. The injection volume of the extraction solution was $5 \mu \mathrm{l}$ with a 5:1 split ratio and an injection temperature of $250^{\circ} \mathrm{C}$. Helium is used as a carrier gas with a speed of $0.8 \mu \mathrm{l}$ per min. The column temperature was set at $70^{\circ} \mathrm{C}$ with an increase of $50^{\circ} \mathrm{C}$ per min. When the temperature reaches $200^{\circ} \mathrm{C}$, it remains constant for $1 \mathrm{~min}$ and then increases at a rate of $20^{\circ} \mathrm{C} / \mathrm{min}$ until the temperature reaches $280^{\circ} \mathrm{C}$. The temperature remains constant for $28 \mathrm{~min}$. The mass spectrometer was operated in electron ionization mode with a voltage of $70 \mathrm{eV}$

\section{Identification of phytochemical compounds}

GC-MS mass spectrum identification was carried out with reference to the National Institute of Standards and Technique database with a factor of fit $\geq 90 \%$ [18]. Percentage of the relative abundance of each compound was calculated by comparing the average peak area with the total area.

In vitro screening test of cancer cell cytotoxicity and data analysis Cytotoxic activity against breast cancer cells (MCF-7) performed by MTT assay method. $100 \mu \mathrm{L}$ of suspension $10^{3}$ cells were cultured and seeded into 96 -well disk plate, and incubated at $37^{\circ} \mathrm{C}$ for $24 \mathrm{~h} .100 \mu \mathrm{L}$ of medium containing rodent tuber extract with serial concentration obtained $1000,500,250,125$, and $62.5 \mu \mathrm{g} / \mathrm{mL}$ of test solution added to each well and the dish was incubated at $37^{\circ} \mathrm{C}$ for $24 \mathrm{~h}$. At the end of the incubation, the culture media containing the sample was removed and washed with $100 \mu \mathrm{L}$ phosphate-buffered saline. In each single well was added $100 \mu \mathrm{L}$ of culture medium containing MTT and reincubated for $4 \mathrm{~h}$ at $370^{\circ} \mathrm{C}$. The live cells will react with MTT to form purple formazan. After $4 \mathrm{~h}$, at each well, the stopper reagent was added to kill cells and dissolved formazan crystals. Plate in a shaker for $10 \mathrm{~min}$, then incubated at room temperature in a dark room overnight. Furthermore, the absorbance of each well was read by the ELISA reader with absorbance at a wavelength of $595 \mathrm{~nm}$, and the percentage of cell viability of MCF-7 or cell proliferation inhibition percentage was calculated. A dose of test solution that reduces survival by half maximal inhibitory concentration $\left(\mathrm{IC}_{50}\right)$ was calculated. Cisplatin was used as a positive control while control plant was used as a negative control. The cytotoxic activity of rodent tuber mutant plants was expressed with $\mathrm{IC}_{50}$ values obtained through a linear regression analysis between the logarithm of the concentration of the test material and the percentage of MCF-7 cell viability.

\section{RESULTS}

The bioactive compounds in the tuber of mutant clones extract have been identified using GC-MS analysis. Based on the GC-MS analysis, there were differences in the phytochemical composition between the tuber of control and mutant plants (Table 1). This study evaluated that the phytochemical composition in the tubers of KB 6-1-3-4 and KB 6-9-5 mutant clones was increased and found new bioactive compounds which not present in the control plant (Table 1). The tubers of mutant clones contained several new anticancer compounds which were not found in control (Table 2 and Fig. 1).

The results of this study revealed that six bioactive compounds from fatty acid have potential as anticancer activity is octadecanoic acid, hexadecanoic acid, hexadecanoic acid methyl ester, 9-octadecanoic acid, linolelaidic acid methyl ester, and butanoic acid (Table 2). Some anticancer compounds in mutant clones have a higher amount than control plant. The most potential target as anticancer properties among six bioactive compounds from fatty acid is octadecanoic acid and hexadecanoic acid. Octadecanoic acid has the most different anticancer properties with the relative abundance. The octadecanoic acid was absent in the control plant. As shown in Table 2, octadecanoic acid in the KB 6-9-5 has higher concentrations of about $85.03 \%$. This study confirmed that KB 6-9-5 has potency as anticancer agent 2 times greater than KB 6-1-3-4 mutant clones.

Table 1: Phytochemical composition in the tubers extraction of rodent tuber control and mutant clones based on GC-MS

\begin{tabular}{|c|c|c|c|c|c|c|}
\hline \multirow[t]{2}{*}{ Name of compound } & \multicolumn{3}{|l|}{ RT } & \multicolumn{3}{|c|}{ Area percentage } \\
\hline & Control & $6-1-3-4$ & $6-9-5$ & Control & $6-1-3-4$ & $6-9-5$ \\
\hline Hexadecanoic acid & 31.954 & 28.889 & 28.861 & 22.08 & 4.46 & 3.99 \\
\hline Hexadecanoic acid, methyl ester & $\mathrm{NI}$ & 28.331 & $\mathrm{NI}$ & $\mathrm{NI}$ & 2.86 & NI \\
\hline Octadecanoic acid & $\mathrm{NI}$ & 89 & 30.144 & $\mathrm{NI}$ & 8.07 & 85.03 \\
\hline 9-Octadecanoic acid, methyl ester & NI & 29.517 & $\mathrm{NI}$ & $\mathrm{NI}$ & 2.39 & NI \\
\hline 9,12 -Octadecadienoic acid & 33.078 & $\mathrm{NI}$ & NI & 38.37 & NI & $\mathrm{NI}$ \\
\hline Campesterol & 40.532 & NI & NI & 1.55 & NI & $\mathrm{NI}$ \\
\hline Alpha-monopalmitin & $\mathrm{NI}$ & $\mathrm{NI}$ & 38.439 & NI & $\mathrm{NI}$ & 1.07 \\
\hline Stigmasterol & 40.966 & NI & $\mathrm{NI}$ & 4.05 & NI & $\mathrm{NI}$ \\
\hline Butanoic acid & $\mathrm{NI}$ & 28.820 & $\mathrm{NI}$ & NI & 2.53 & $\mathrm{NI}$ \\
\hline 2-Acetyl-2-thiazoline & NI & $\mathrm{NI}$ & 29.510 & $\mathrm{NI}$ & $\mathrm{NI}$ & 1.09 \\
\hline Linolelaidic acid, methyl ester & NI & 29.489 & $\mathrm{NI}$ & NI & 6.09 & $\mathrm{NI}$ \\
\hline N-Acetyl-d, 1-norleucenine & NI & 29.648 & NI & $\mathrm{NI}$ & 2.23 & NI \\
\hline 11-Dodecenyl trifluoroacetate & $\mathrm{NI}$ & 29.985 & $\mathrm{NI}$ & $\mathrm{NI}$ & 47.64 & $\mathrm{NI}$ \\
\hline 1-Acetoxynonane & $\mathrm{NI}$ & 31.571 & NI & $\mathrm{NI}$ & 2.72 & $\mathrm{NI}$ \\
\hline 1,5-Heptadiene, 3,3,5-trimethyl & NI & 38.543 & NI & NI & 4.93 & NI \\
\hline
\end{tabular}

Table 2: Fatty acid composition as anticancer properties in the tubers extraction of rodent tuber mutant clones

\begin{tabular}{|c|c|c|c|c|c|c|}
\hline \multirow[t]{2}{*}{ Anticancer properties reference } & \multirow[t]{2}{*}{ Name of the compound } & \multirow[t]{2}{*}{ Nature of the compound } & \multicolumn{2}{|l|}{ RT } & \multicolumn{2}{|c|}{ Area percentage } \\
\hline & & & $6-1-3-4$ & $6-9-5$ & $6-1-3-4$ & $6-9-5$ \\
\hline$[19,20]$ & Hexadecanoic acid & Palmitic acid & 28.889 & 28.861 & 4.46 & 3.99 \\
\hline [21] & Hexadecanoic acid, methyl ester & Palmitic acid, methyl ester & 28.331 & $\mathrm{NI}$ & 2.86 & NI \\
\hline$[19,22]$ & Octadecanoic acid & Stearic acid & 89 & 30.144 & 8.07 & 85.03 \\
\hline$[19,23]$ & 9-Octadecanoic acid, methyl ester & Omega-9/elaidic acid & 29.517 & $\mathrm{NI}$ & 2.39 & NI \\
\hline [2] & Linolelaidic acid, methyl ester & Omega-6 & 29.489 & $\mathrm{NI}$ & 6.09 & $\mathrm{NI}$ \\
\hline [25-27] & Butanoic acid & Butyric acid & 28.820 & $\mathrm{NI}$ & 2.53 & $\mathrm{NI}$ \\
\hline
\end{tabular}




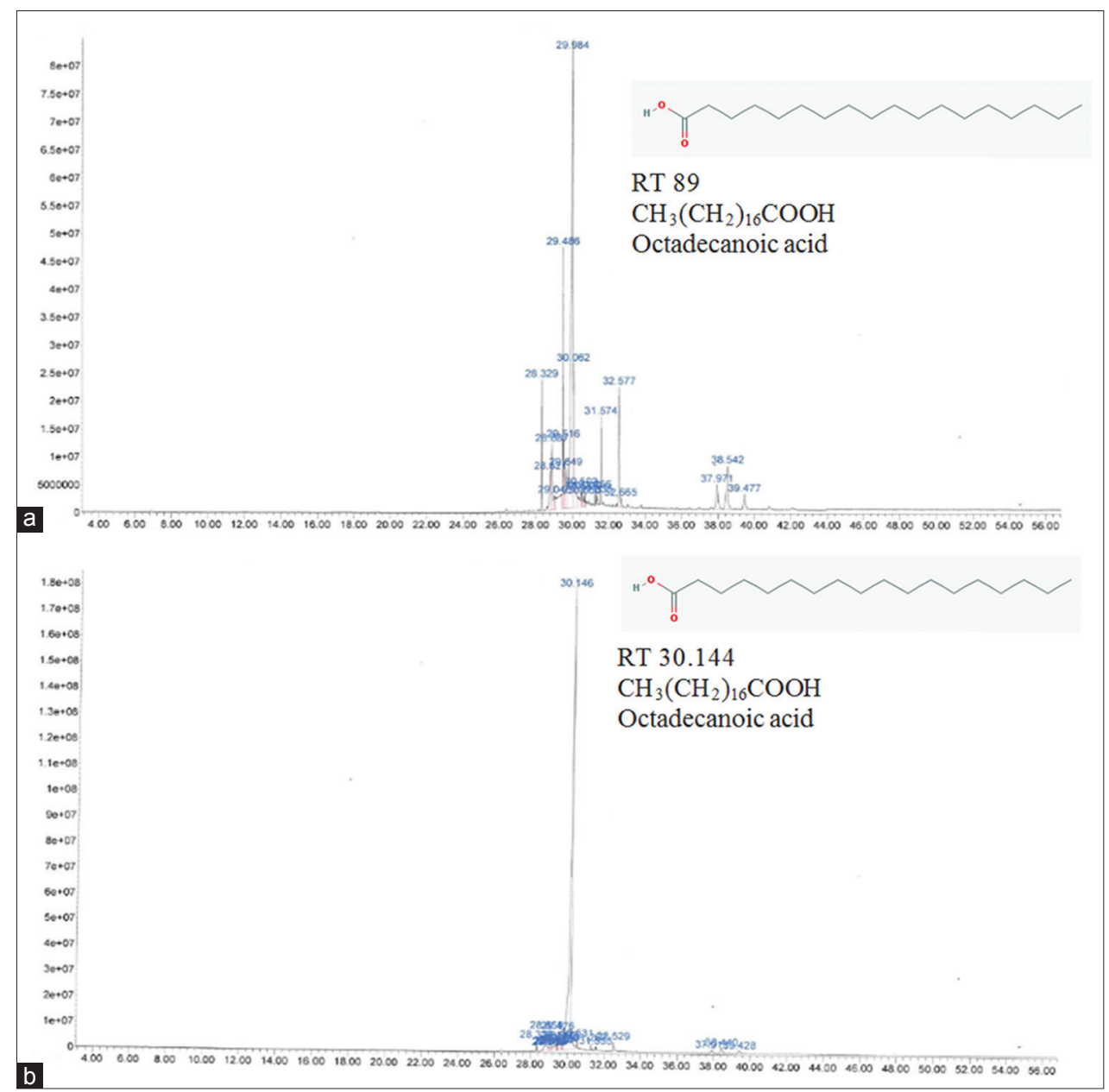

Fig. 1: Gas chromatography-mass spectrometry analysis of the ethanol extract of tuber (a) KB 6-1-3-4 and (b) KB 6-9-5

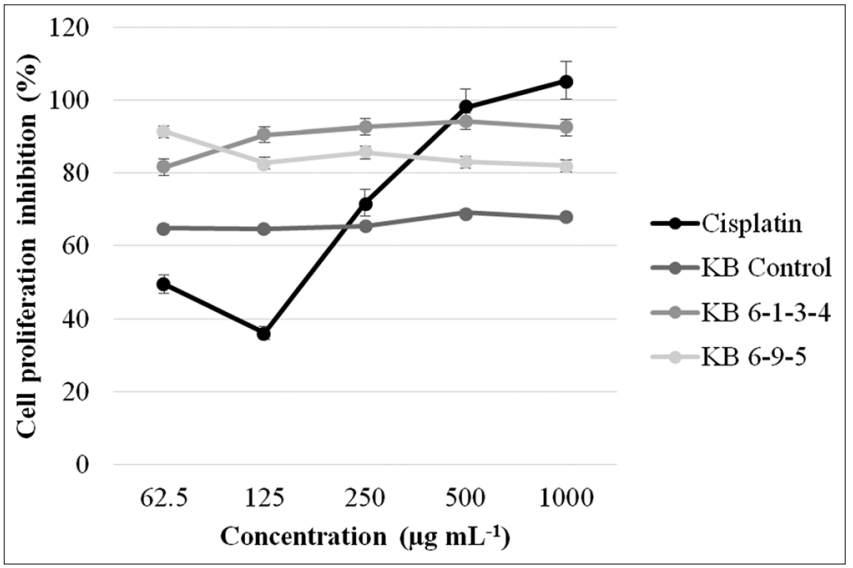

Fig 2: The graph represents the cell proliferation inhibition of tuber mutant plants (KB 6-1-3-4 and KB 6-9-5) against MCF-7 breast cancer cell lines at different concentrations $\left(62.5-1000 \mu \mathrm{g} \mathrm{m}^{-1}\right)$. Data were plotted as a percentage of cell proliferation inhibition and represented as mean \pm standard error mean (SEM) of three independent experiments

The result of MTT assays was obtained from the linear regression equation between concentration and percent of living cells. The results showed that the tubers extract from two mutant clones significantly inhibited the MCF-7 cell line and had potent extract with IC $_{50}$ value of $12.482 \mu \mathrm{g} / \mathrm{mL}$ from KB 6-1-3-4 and 7.043 $\mu \mathrm{g} / \mathrm{mL}$ from KB 6-9-5. All the tubers extract from two mutant clones showed cytotoxic effect toward MCF-7 cell line.
According to the U.S. The National Cancer Institute (NCI), a compound has cytotoxic activity if it has $\mathrm{IC}_{50}$ values of $<20 \mu \mathrm{g} / \mathrm{mL}[28,29]$. Based on the $\mathrm{IC}_{50}$ values of the two rodent tuber mutant plants, the $\mathrm{IC}_{50}$ values of $<20 \mu \mathrm{g} / \mathrm{mL}$ so that it can be confirmed that both KB 6-1-3-4 and KB 6-9-5 have cytotoxic activity against MCF-7 cell line. The results of this study showed a linear relationship between $\mathrm{IC}_{50}$ values of $\mathrm{KB}$ 6-1-3-4 and KB 6-9-5 with a percentage of viability of living cells (Fig. 2). The IC $\mathrm{I}_{50}$ value of the control rodent tuber plant was $19.1131 \mu \mathrm{g} / \mathrm{mL}$. The result of MTT assay on rodent tuber mutant plant's extract KB 6-9-5 was 3 times more effective than compared to control plant.

\section{DISCUSSION}

Octadecanoic acid or stearic acid is a saturated fatty acid found in relatively high concentrations in some foods. Octadecanoic acid or stearic acid is the primary metabolites present in plants which form of glycerol esters [30]. Stearic acid has been reported to inhibit the development of human breast cancer cells in proliferation in vitro [31-33] and in vivo [34]. Stearic acid has also been shown to induce apoptosis in breast cancer cells and inhibit cell cycle of breast tumors [35,36]. Interestingly, epidemiological studies have also shown that stearic acid has the potential to prevent and treat breast cancer [37].

Hexadecanoic acid or palmitic acid has been shown to have antitumor activity in mouse models and is cytotoxic selective for MOLT-4 leukemia cancer cells due to their interaction with DNA topoisomerase I and their ability to induce apoptosis [24]. Palmitic acid was present in Solanum nigrum which had a role induce apoptosis on cervical cancer cell lines [38]. The hexadecanoic acid methyl ester is also able to inhibit growth and induce apoptosis of human gastric cancer cells [39]. Hexadecanoic acid methyl ester has been found to have anti- 
inflammatory, antioxidant, hypocholesterolemic, 5-alpha reductase inhibitors, nematicide, pesticides, and antiandrogenic [40].

Fatty acid compounds in herbal plants have a role as chemopreventive agents or cause cell cycle inhibition and trigger apoptosis in cancer cells [41]. The results of this study revealed that a lower $\mathrm{IC}_{50}$ value indicates a higher anticancer activity. This study shows that the fatty acids from octadecanoic acid and hexadecanoic acid are responsible for their pharmacological activity and their extract produces a chemopreventive agent effect or causes inhibition of the growth cycle of cancer cells [42]. The rodent tuber mutant plants showed a potential source that can be used as an alternative treatment for breast cancer from natural ingredients. In the previous study, Purwaningsih et al. [43] conducted cytotoxic tests from the leaves of rodent tuber extracts against HeLa and MCF-7 cells produced $\mathrm{IC}_{50}$ values of $30.19 \mu \mathrm{g} / \mathrm{mL}, 5.58$ $\mu \mathrm{g} / \mathrm{mL}$, respectively, whereas in the study of Purwaningsih et al. [44,45] obtained by rodent tuber extract can reduce telomerase expression in HeLa and Raji cells.

This study showed that KB 6-1-3-4 and KB 6-9-5 extracts have the strong potential as anticancer agents through inhibition of MCF-7 cancer cell. Mohan et al. [4] have examined that the cytotoxic effects of the crude extracts of rodent tuber plants using dichloromethane and ethyl acetate on leukemia cancer cells (T4-lymphoblastoid CEM-ss) have a significant effect in inhibiting cell invasion and experiencing apoptosis for $72 \mathrm{~h}$, at $\mathrm{IC}_{50}$ values of 6.5 and $8.2 \mu \mathrm{g} / \mathrm{mL}$. Antitumor and cytotoxic effects have been observed for the chemical compounds methyl esters [46] and other evidence suggests that amino acid methyl esters produce high cytotoxic effects on MCF-7 cells [35]. In addition, as shown in the study of Hardy et al. [47], octadecanoic acid induces apoptosis of breast cancer cells through mechanisms that might have implications for increased cardiolipin replacement and a reduction of mitochondrial phospholipids.

\section{CONCLUSION}

Mutant clones of KB 6-1-3-4 and KB 6-9-5 concluded that have an important role and offer a new potential promising as anticancer agents on breast cancer cell. Octadecanoic acid (stearic acid) and hexadecanoic acid (palmitic acid) are the major role of bioactive compounds as anticancer. The cytotoxicity test through MTT on MCF-7 cancer cells obtained by $\mathrm{KB}$ 6-9-5 mutant clone has higher $\mathrm{IC}_{50}$ values of $7.043 \mu \mathrm{g} / \mathrm{mL}$ which compared with the $\mathrm{IC}_{50}$ values in control plants about $19.113 \mu \mathrm{g} / \mathrm{mL}$. KB 6-9-5 mutant clone has greater effectiveness up to 5 times compared to control plants. KB 6-1-3-4 and KB 6-9-5 showed more effective as anticancer against in vitro MCF-7 breast cancer cells. The further study is needed to investigate the effect of rodent tuber mutant plants extract on activity apoptosis and telomerase in MCF-7 breast cancer cell lines.

\section{ACKNOWLEDGEMENT}

This work was funded by the Minister of Research, Technology, and Higher Education grant No: 036/VR.RTT/IV/2018. We also would like to thank Padjadjaran University, Laboratorium Central for providing the cell line and Dr. Yuni Elsa for her assistance in the MTT assay analysis.

\section{AUTHORS' CONTRIBUTIONS}

All authors declare that they have participated sufficiently in the work to take public responsibility for the content, including participation in the concept, design, analysis, writing, or revision of the manuscript.

\section{CONFLICTS OF INTEREST}

All authors declare that this material or similar material has not been and will not be submitted to or published in any other publication. There are no any potential conflicts of interest.

\section{REFERENCES}

1. Essai. Medicinal Herbs Index in Indonesia. Jakarta: PT Essai Indonesia; 1986.
2. Lai CS, Mas RH, Nair NK, Majid MI, Mansor SM, Navaratnam V, et al. Typhonium flagelliforme inhibits cancer cell growth in vitro and induces apoptosis: An evaluation by the bioactivity guided approach. J Ethnopharmacol 2008;118:14-20.

3. Mankaran S, Dinesh K, Deepak S, Gurmeet S. Typhonium flagelliforme: A multipurpose plant. Int Res J Pharm 2013;4:45-8.

4. Mohan S, Bustamam A, Ibrahim S, Al-Zubairi AS, Aspollah M. Anticancerous effect of Typhonium flagelliforme on human T4Lymphoblastoid cell line CEM-ss. J Toxicol Pharmacol 2008;3:449-56.

5. Mohan S, Abdul AB, Abdelwahab SI, Al-Zubairi AS, Aspollah Sukari M, Abdullah R, et al. Typhonium flagelliforme inhibits the proliferation of murine leukemia WEHI-3 cells in vitro and induces apoptosis in vivo. Leuk Res 2010;34:1483-92.

6. Mohan S, Bustamam A, Ibrahim S, Al-Zubairi AS, Aspollah M, Abdullah $\mathrm{R}$, et al. In vitro ultramorphological assessment of apoptosis on CEMss induced by linoleic acid-rich fraction from Typhonium flagelliforme tuber. Evid Based Complement Alternat Med 2011;2011:421894.

7. Sianipar NF, Laurent D, Purnamaningsih R, Darwati I. The Effect of Gamma Irradiation and Somaclonal Variation on Morphology Variation of Mutant Rodent Tuber (Typhonium flagelliforme Lodd) Lines. Indonesia: Proceeding International Conference on Biological Science ICBS UGM; 2013.

8. Sianipar NF, Purnamaningsih R, Gumanti DL, Rosaria, Vidianty M. Analysis of gamma irradiated-third generation mutants of rodent tuber (Typhonium flagelliforme Lodd.) based on morphology, RAPD, and GC-MS markers. Pertanika J Trop Agric Sci 2017;40:185-202.

9. Sianipar NF, Purnamaningsih R, Gumanti DV, Rosaria, Vidianty M. Analysis of gamma irradiated fourth generation mutant of rodent tuber (Typhonium flagelliforme Lodd.) based on morphology and RAPD markers. J Teknol 2016;78:41-9.

10. Sianipar NF, Purnamaningsih R, Chelen C. Effect of gamma irradiation on protein profile of rodent tuber (Typhonium flagelliforme Lodd.) in vitro mutant based on 1D and 2D page analyses. J Teknol 2016;78:35-40.

11. Sianipar NF, Purnamaningsih R. Enhancement of the contents of anticancer bioactive compounds in mutant clones of rodent tuber (Typhonium flagelliforme Lodd.) based on GC-MS analysis. Pertanika J Trop Agric Sci 2018;41:305-20.

12. Marimuthu S, Padmaja B, Nair S. Phytochemical screening studies on Melia orientalis by GC-MS analysis. Pharmacognosy Res 2013;5:216-8.

13. Nishaa S, Vishnupriya M, Sasikumar JM, Gopalakrishnan VK. Phytochemical screening and GC-MS analysis of ethanolic extract of rhizomes of Maranta arudinacea L. Res J Pharm Biol Chem Sci 2013;4:52-9.

14. Nurrochmad A, Lukitaningsih E, Meiyanto E. Anticancer activity of rodent tuber (Typhonium flagelliforme (Lodd.) blume on human breast cancer T47D cells. Int J Phytomed 2011;2:138-46.

15. Munshi A, Hobbs M, Meyn RE. Clonogenic cell survival assay. Methods Mol Med 2005;110:21-8

16. Rajendran V, Jain MV. In vitro tumorigenic assay: Colony forming assay for cancer stem cells. Methods Mol Biol 2018;1692:89-95.

17. Durgawale TP, Khanwelkar CC, Durgawale PP. Phytochemical analysis of Portulaca oleracea and Portulaca quadrifida extracts using gas chromatography-mass spectrometry. Asian J Pharm Clin Res 2018;11:204-7.

18. Praptiwi P, Fathoni A. Phytochemical, gas chromatography-mass spectrometry profiling and free radical scavenging activity of Exocarpos longifolius (Santalaceae) extracts. Asian J Pharm Clin Res 2018;11:452-6

19. Lakshmi PT, Rajalakshmi P. Identification of phyto-components and its biological activities of Aloe vera through the gas chromatography-mass spectrometry. Int Res J Pharm 2011;2:247-9.

20. Yoo YC, Shin BH, Hong JH, Lee J, Chee HY, Song KS, et al. Isolation of fatty acids with anticancer activity from Protaetia brevitarsis Larva. Arch Pharm Res 2007;30:361-5.

21. Harada H, Yamashita U, Kurihara H, Fukushi E, Kawabata J, Kamei Y, et al. Antitumor activity of palmitic acid found as a selective cytotoxic substance in a marine red alga. Anticancer Res 2002;22:2587-90.

22. Khan AA, Alanazi AM, Jabeen M, Chauhan A, Abdelhameed AS. Design, synthesis and in vitro anticancer evaluation of a stearic acidbased ester conjugate. Anticancer Res 2013;33:2517-24.

23. Brueckner B, Rius M, Markelova MR, Fichtner I, Hals PA, Sandvold ML, et al. Delivery of 5-azacytidine to human cancer cells by elaidic acid esterification increases therapeutic drug efficacy. Mol Cancer Ther 2010;9:1256-64.

24. Chujo H, Yamasaki M, Nou S, Koyanagi N, Tachibana H, Yamada K, et al. Effect of conjugated linoleic acid isomers on growth factor- 
induced proliferation of human breast cancer cells. Cancer Lett 2003;202:81-7.

25. Inagaki A, Sakata T. Dose-dependent stimulatory and inhibitory effects of luminal and serosal n-butyric acid on epithelial cell proliferation of pig distal colonic mucosa. J Nutr Sci Vitaminol (Tokyo) 2005;51:156-60.

26. Kim SW, Hooker JM, Otto N, Win K, Muench L, Shea C, et al. Wholebody pharmacokinetics of HDAC inhibitor drugs, butyric acid, valproic acid and 4-phenylbutyric acid measured with carbon-11 labeled analogs by PET. Nucl Med Biol 2013;40:912-8.

27. Komata T, Kanzawa T, Nashimoto T, Aoki H, Endo S, Kon T, et al. Histone deacetylase inhibitors, N-butyric acid and trichostatin A, induce caspase-8-but not caspase-9-dependent apoptosis in human malignant glioma cells. Int J Oncol 2005;26:1345-52.

28. Abdel-Hameed ES, Salih A, Bazaid SA, Shohayeb MM, El-Sayed MM, El-Wakil EA. Phytochemical studies and evaluation of antioxidant, anticancer and antimicrobial properties of Conocarpus erectus L. growing in Taif, Saudi Arabia. Eur J Med Plants 2012;2:93-12.

29. Boik J. Natural Compounds in Cancer Therapy. Minnesota, USA: Oregon Medical Press; 2001

30. Rahmoune B, Zerraouk IZ, Morsli A, Khelifi-Slaoui M, Khelifi L, Amarante LD. Phenylpropanoids and fatty acids levels in roots and leaves of Datura stramonium and Datura innoxia. Int J Pharm Pharm Sci 2017;9:150-4.

31. Evans LM, Cowey SL, Siegal GP, Hardy RW. Stearate preferentially induces apoptosis in human breast cancer cells. Nutr Cancer 2009;61:746-53.

32. Hardy RW, Wickramasinghe NS, Ke SC, Wells A. Fatty acids and breast cancer cell proliferation. Adv Exp Med Biol 1997;422:57-69.

33. Wickramasinghe NS, Jo H, McDonald JM, Hardy RW. Stearate inhibition of breast cancer cell proliferation. A mechanism involving epidermal growth factor receptor and G-proteins. Am J Pathol 1996;148:987-95.

34. Evans LM, Toline EC, Desmond R, Siegal GP, Hashim AI, Hardy RW, et al. Dietary stearate reduces human breast cancer metastasis burden in athymic nude mice. Clin Exp Metastasis 2009;26:415-24.

35. Iyer VV, Griesgraber GW, Radmer MR, McIntee EJ, Wagner CR. Synthesis, in vitro anti-breast cancer activity, and intracellular decomposition of amino acid methyl ester and alkyl amide phosphoramidate monoesters of 3'-azido-3'-deoxythymidine (AZT).
J Med Chem 2000;43:2266-74.

36. Li C, Zhao X, Toline EC, Siegal GP, Evans LM, Ibrahim-Hashim A, et al. Prevention of carcinogenesis and inhibition of breast cancer tumor burden by dietary stearate. Carcinogenesis 2011;32:1251-8.

37. Saadatian-Elahi M, Norat T, Goudable J, Riboli E. Biomarkers of dietary fatty acid intake and the risk of breast cancer: A meta-analysis. Int J Cancer 2004;111:584-91.

38. Paul S, Kundu R. Induction of apoptosis by fatty acid rich fraction of Solanum nigrum on cervical cancer cell lines. Int J Pharm Pharm Sci 2017:9:199-206

39. Yu FR, Lian XZ, Guo HY, McGuire PM, Li RD, Wang R, et al. Isolation and characterization of methyl esters and derivatives from Euphorbia kansui (Euphorbiaceae) and their inhibitory effects on the human SGC7901 cells. J Pharm Pharm Sci 2005;8:528-35.

40. Kim YS, Li XF, Kang KH, Ryu B, Kim SK. Stigmasterol isolated from marine microalgae Navicula incerta induces apoptosis in human hepatoma hepG2 cells. BMB Rep 2014;47:433-8.

41. Mericli F, Becer E, Kabaday1 H, Hanoglu A, Yigit Hanoglu D, Ozkum Yavuz D, et al. Fatty acid composition and anticancer activity in colon carcinoma cell lines of Prunus dulcis seed oil. Pharm Biol 2017;55:1239-48

42. Sabithira G, Udayakumar R. GC-MS analysis of methanolic extracts of leaf and stem of Marsilea minuta (Linn.). J Altern Complement Med 2017;3:1-13.

43. Purwaningsih E, Widayanti E, Suciati Y. Cytotoxicity assay of Typhonium flagelliforme Lodd against breast and cervical cancer cells. Univ Med 2014;33:75-82.

44. Purwaningsih E, Suciati Y, Widayanti E. Typhonium flagelliforme decreases telomerase expression in HeLa cervical cancer cells. Univ Med 2016;35:3-9.

45. Purwaningsih E, Suciati Y, Widayanti E. Anticancer effect of a Typhonium flagelliforme $\mathrm{L}$. in raji cells through telomerase expression. Indones J Cancer Chemoprevent 2017;8:15-20.

46. Jin G, You Y, Ahn B. Esters of 2-(1-hydroxyalkyl)-1,4-dihydroxy-9,10anthraquinones with melphalan as multifunctional anticancer agents. Bioorg Med Chem Lett 2001;11:1473-6.

47. Hardy S, El-Assaad W, Przybytkowski E, Joly E, Prentki M, Langelier Y, et al. Saturated fatty acid-induced apoptosis in MDA-MB-231 breast cancer cells. A role for cardiolipin. J Biol Chem 2003:278:31861-70. 